\title{
The analysis of institutional organization of science of education management as a factor of development of education research methodology
}

\author{
T. V.Sych \\ Luhansk Taras Shevchenko National University, Ukraine, Starobelsk \\ Corresponding author. E - mail: tatynasych@gmail.com
}

Paper received 12.05.18; Accepted for publication 21.05.18.

https://doi.org/10.31174/SEND-PP2018-170VI70-13

\begin{abstract}
The article presents the characteristic of institutional organization of science of management education as a factor in the development of the methodology of education management research. Academic institutions dealing with the research on education management issues; educational systems that reproduce the relevant scientific staff; state and public structures that direct scientific and pedagogical activity in this field; means of communication in this area, specialized professional scientific publications; international donor organizations and foundations that support research on education management issues are considered.
\end{abstract}

Keywords: institutionalization of science, education management, the development of theory of education management, methodology development, methodology of education management research.

Introduction. Institutionalization is an integral part of the development and differentiation of society and is considered as a process of the emergence and formation of social institutions - the key structural elements of society. One of such social institution is science, which provides the production of knowledge accumulation, as well as their use in practice. The institutionalization of science reflects the current tendency towards the differentiation of scientific knowledge as an important factor in the development of pedagogical science, the formation of new scientific theories, the specialization of scientific disciplines, in particular the theory of education management. The functional purpose of institutes of organization of education management science is implementation regulatory, integration, communicative processes and recreation scientific personnel in the field of education management [2]. According to the results of the analysis of the formation of institutes of science management education, we can draw the conclusions about the development of the methodology of education management research. The effect of certain methodological norms on the implementation and scientific research publication in this field, the mechanisms for the formation of scientific problems and the protection of dissertation research testify these conclusions.

Brief review of publications on the topic. Some aspects of institutionalization of science in education management are considered in the works of O. Adamenko, N. Vasiniova, V. Kurilo, V. Lunyachek, V. Ponomarenko, I. Teleshova, E. Khrykova, S. Yablochnikova and others. The issue of the training of education managers was rewied by E. Bereznyak, V. Bondar, T. Borova, Y. Vasiliev, B. Gershunsky, V. Goromovyi, G. Yelnikov, A. Ermola, I. Zhernosek, O. Zaichenko, O. Kasyanova, S. Klepko, N. Klokar, V. Kremen, V. Lazarev, V. Lugovyi, T. Lukina, A. Marmaza, V. Maslov, V. Oliynyk, L. Parashchenko, G. Polyakova, M. Portnov, M. Potashnik et al., institutionalization in the aspect of the development of different parts of the system of education is considered in the rites of V. Andrushchenko, I. Gancherenok, Z. Zhukovska, L. Kvasova, V. Frolov, V. Senashenko, O. Sidorenko, T.V. Topchii (continuing education in Ukraine); V. Andrushchenko, O. Antonova, S. Vitvitska, L. Gorbunova, M. Zubrytska, K. Korsak, M. Kultaeva, S. Kurbatova, N. Myronchuk, N. Sydorchuk (higher education in Ukraine) and others. So E. Khrykov determines institutionalization among the criteria of the development of pedagogical science, which is demonstrated by the creation of the Academy of Pedagogical Sciences, the system of research institutes, specialized councils for the defence of dissertations, periodical professional publications [8]. In our opinion, this is not a complete list of indicators of the institutional organization of science education management. $\mathrm{N}$. Vasyniova establishes the criterion "Institutional design of the scientific field" in her study of the development of theory of management of higher education. She notes that any period of the development of theory of higher educational institutions management is characterized by the presence of prominent scholars, science schools and centers, whose activities had a decisive influence on the development of pedagogical thought and the development of management theory of higher educational institutions in Ukraine; the change of organizational forms of science, as well as the inclusion of new historical and pedagogical sources in the scientific circulation; the formation of a school of science (or schools), whose scope would include studying the theory of management of higher education institutions in Ukraine [1]. V. Kurilo considered the development of the system of scientific and pedagogical communication, the nature of scientific production, and the range of scholar in his study "Formation and development of the system of education and pedagogical thought of the East Ukrainian region in the twentieth century" [5], However, a complex study of the institutional organization of science in education management in Ukraine was not implemented.

The purpose of the article is a description of the institutional organization of education management science as a factor in the development of the methodology of education management research.

Materials and methods. Different forms of institutionalization of education management have been analyzed. The analysis of educational institutions that deal with education management training and scholars that develop education management issues have been carried out. The institutions that regulate, support, and carry out research on education management issues have been investigated. Repository of the V.I. Vernadsky National Library of Ukraine has been studied for availability of periodicals on the problems of education management. The protocols of approval of the topics of the dissertation research specialty 13.00 .06 - "Theory and methods of education management" for the period from 2008 to 2018 have been analyzed on the website of the Interdepartmental 
Council for the Coordination of Researches in the field of Education, Pedagogy and Psychology, which is at the National Academy of Pedagogical Sciences. We have studied the sites of specialized academic councils of the University of Education Management of the National Academy of Sciences of Ukraine, Luhansk Shevchenko National University, Cherkasy Khmelnitsky National University where the doctoral and candidate's theses are defended in the specialty 13.00.06 - "Theory and methodology of education management". The dynamics of the number of protected topics in this specialty for the period from 2008 to 2018 in relation to the approved topics have been analyzed.

The results and their discussion. As a result of the analysis of scientific literature, which covers this issue, we have identified the following forms of institutionalization of science in the field of education management: academic institutions that deal with research on education management issues (research centers, research institutes, etc.); educational systems that reproduce the relevant scientific staff (universities, institutes); state structures that direct scientific and pedagogical activities in this field (information and analytical centers, advisory councils, specialized councils for the defense of dissertations); public organizations that deal with education management issues (academies, associations, consortia, unions); permanent workshops and periodic conferences, symposiums, working meetings on the issues of education management; specialized professional scientific publications; international donor organizations and foundations that support research on education management issues.

The consideration of the availability of academic institutions involved in the study of education management issues provided the following results. The academic level of research on education management issues is usually carried out by university departments, primarily at national pedagogical universities. Among the academic institutions that study problems of education management, the undisputed leadership belongs to the Academy of Pedagogical Sciences of Ukraine (APSU of Ukraine). This "highest state scientific institution" was established in 1992. Among the network of institutes under the APS of Ukraine, the special role in the study of education management issues belongs to the institutes of pedagogy, pedagogical education and adult education, the Central Institute of Postgraduate Education and its affiliates, the Institute of Higher Education, the University of Management Education [6]. Specialized research institutions that deal exclusively with research on education management issues in Ukraine are absent.

An integral part of the process of institutionalization is the formation of a scientific community that studies issues of education management. First and foremost, this is the training of scientific staff on the basis of higher education institutions. In due time, the University of Management of Education of the National Academy of Pedagogical Sciences of Ukraine and Taras Shevchenko Luhansk National University became the peculiar "forge" of education management personnel. It was at these institutions that specialized scientific councils for defence of doctoral and candidate's theses were stated at the specialty 13.00.06 - "Theory and methodology of education management". At the end of 2013, a specialized academic council for the defense of theses was created on the specialty 13.00.06 at the Bohdan Khmelnytsky National University of Cherkasy. However, the geography of the implementation of scientific and pedagogical research in this area extends beyond these scientific centers, it is much wider. These are actually all the regions of our state from Uzhgorod to Luhansk. It should be noted that for quite a long time the indicated direction of training was absent in the classifier of scientific specialties. Only in September 2006, by the Resolution No. 6-06 / 8 of the Presidium of the Higher Attestation Commission of Ukraine, the name of the specialty 13.00.06 was approved in the new wording and the constituent contents of its passport (classification characteristics, research directions, etc.). In accordance with the Resolution of the Cabinet of Ministers of Ukraine "On Approval of the List of Fields of Knowledge and Specialties under which Higher Education Recipients are Prepared" dated April 29, 2015, No. 266, specialty 13.00 .06 - "Theory and Methodology of Education Management" corresponds to the specialty 011 Educational, Pedagogical science, specialization "Theory and methodology of education management".

The first theses for obtaining a scientific degree of a candidate of pedagogical sciences in specialty 13.00.06 were presented for defense in 2008. Their protection took place in the specialized boards of the University of Management of Education of the National Academy of Sciences of Ukraine (A. Guralyuk, N. Popova, O.Bodnar, N.Murovana) and Lugansk Shevchenko National University (S. Burdina). The first scientific research at the qualification level of the Doctor of Sciences in Management of Education was defended in 2008 at the specialized academic council of the University of Management of Education of the National Academy of Sciences of Ukraine. This was a doctoral dissertation by L.Kalinina "The Information Management System for a General Educational Institution". In general, from June 2008 to December 2017, 127 scholars and educators defended dissertations in specialty 13.00.06 - Theory and Methods of Education Management and received appropriate confirmation from the Attestation Board of the Ministry of Education and Science of Ukraine, thirty of which were doctoral. According to the analysis of the protocols of the interdepartmental council for the coordination of scientific research at the National Academy of Sciences of Ukraine for the period, 72 topics of doctoral dissertation researches and 233 themes of candidate dissertation researches were approved, which together make up 305 topics. This is despite the fact that the problem of education management is also under the cipher of other specialties.

It should be noted that the theory of education management has developed for a long time as a component of pedagogical theory. Selection of specialty 13.00.06 shows the differentiation of pedagogical knowledge. The process of differentiation of scientific knowledge corresponds to the division of labor, specialization in pedagogical and scientific activities. Differentiation finds its embodiment in the system of professional training, advanced training, training of scientific personnel. As Ye.Hrykov notes, the concept of "differentiation" characterizes the structuring of scientific knowledge, scientific disciplines, and the concept of "specialization" characterizes the division of scientific work, its deepening in connection with the complication of educational processes and scientific activity. Among the immediate causes of branch specialization, he highlights the role and complexity of a certain aspect of educational activity, the specialization of types of pedagogical activities, the accumulation of a considerable amount of information on this 
aspect of educational activity, creating more favorable conditions for deepening scientific research [7].

According to its name and logic, the specialty 13.00 .06 should provide the study of managerial problems of all components of education, but the study of managerial problems include passports of other specialties. As Ye.Hrykov notes, the lack of elaboration of the research methodology peculiarities in certain specialties, the lack of research topics in the specialty on the development of methodology - is a major factor in casting doubt on the need to identify a particular specialty and characterizes its initial level of development [7]. However, in the passport of specialty 13.00.06, the directions of research on solving methodological problems are determined, which indicates the attention to this problem. But the analysis of the approved research topic showed that only one of them comprehensively considers this problem, namely the dissertation research of the author of the article "Development of research methodology of education management in the history of native pedagogical science (second half of the XX - the beginning of the XXI century)".

Comparing the number of approved topics in the specialty 13.00.06 allows us to conclude that by 2005 their average number is more than 30 , but in 2017 only 16 topics were approved (Fig. 1).

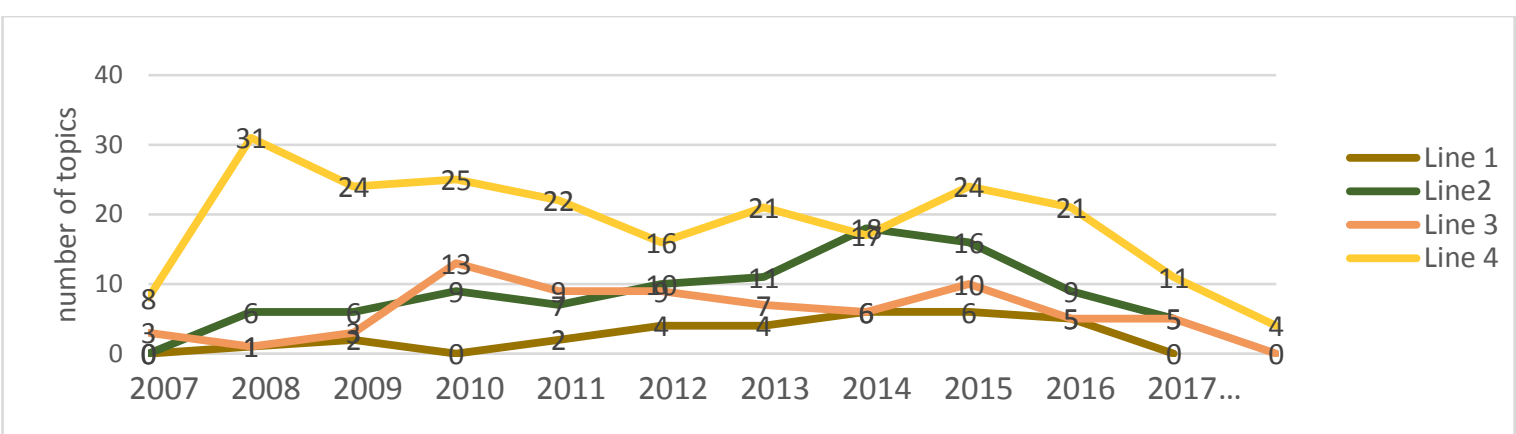

Fig. 1. The analysis of the number of approved and protected topics of the dissertation works in the specialty "Theory and methods of education management"

Line 1 - Protected topics of doctoral theses

Line 2 - Protected topics of $\mathrm{PhD}$ theses

Line 3 - Approved topics of doctoral theses

Line 4 - Approved topics of $\mathrm{PhD}$ theses

This is not indicates waning interest in education management . In our opinion, the decrease in the number of approved topics reflects the general tendency in other specialties. The reasons for this phenomenon can be found in the crisis situation in the country, in the reduced funding research budget, more difficult requirements for the award of scientific degrees, etc. Concidering the ratio of protected topics to the approved is $42 \%$, in a few years there will be few scientists who are investigating the problems of education management in our country. The largest number of protected works in this specialty is observed in 2012-2015. (from 14 in 2012 to 24 in 2015 with a gradual increase). In 2014 there are 14 works, and in 2017, only 5 candidate's theses and no doctorate in the specialization "Theory and Methods of Education Management." Indeed, a large number of theses do not always indicate the development of science, but reflects the number of scientists who are investigating a certain scientific problem area. The quality of research depends on the methodology of their implementation and the availability of regulatory requirements as for the evidence of the results of the study.

Also, the basis for the development of scientific ground in this specialty was the establishment of a master's degree in the field of "Management of an educational institution" in the 90s years of the 20th century on the basis of national universities. The first university in which such a magistracy was opened is Luhansk Shevchenko National University. Training the leading personnel for the sphere of education management and masters in this specialty started at the Kharkiv National Pedagogical University named after G.S. Skovoroda (KHNPU), the Ukrainian Engineering Pedagogical Academy (UIPA), RVNZ "Crimean Humanitarian University ", Sumy State Pedagogical University named after A. S. Makarenko
(SDPU). These establishments were the first in this sphere.[4]. At present, such training is being conducted in more than 25 pedagogical institutions of higher education in Ukraine and in 6 non-pedagogical universities [3]. The history of training the heads of education in the field of "Management of educational institutions" has been in Ukraine for more than twenty years, and in the vast majority of pedagogical universities it is less than 10 years. We agree with V. Lunyachek, who insists on the need for a normative definition of the compulsory level of education for applicants for management positions in the education system of Ukraine. It should be the qualification of a master's degree in the field of "Management of an educational institution", considering the requirements of the present stage of education development and potential possibility of higher education institutions in Ukraine. The education system should be provided by the relevant specialists [4].

An analysis of the development of communicative processes has shown that there are enough scientific and scientific-practical conferences and seminars of different levels, the topics of which are correlated with managerial issues in the field of education in Ukraine and abroad, but the theory of education management continues to develop within pedagogy. So, the publication of articles by scientists is usually carried out in pedagogical editions, newsletters of universities, as well as in periodicals on public administration and even in economic and psychological periodicals. Nowadays, there are two periodicals on the management of education in Ukraine. This is a scientific and practical journal published by the Academy of Sciences of the Higher School of Ukraine, the Ukrainian-American Humanitarian Institute "Wisconsin. International University (USA) in Ukraine" since 1996, namely:" Education and Management". Since 2008, the 
University of Management Education of the National Academy of Pedagogical Sciences of Ukraine issued an electronic scientific specialty magazine "Theory and Methods of Education Management". So the publication of the first periodical specialized magazine is connected with the period when, after isolation in Soviet times, relations with foreign educational institutions were established, the domestic scientific community got access to the achievements of Western management theory. The launch of the second specialized edition coincides with the time of protection of the first theses in the specialty 13.00.06. Since its publication was based on the University of Management Education of the National Academy of Pedagogical Sciences of Ukraine, where a specialized academic council on the defence of theses on this specialty worked at that time, the publication was triggered by the emergence of a new specialty.

With regard to international donor organizations and foundations supporting research, it can be noted that in Ukraine, this manifestation of institutionalization only develops. This will be facilitated by the introduction of grant funding through the National Research Foundation, whose creation is planned in 2018. It is planned that the fund will support, conducting both fundamental and applied researches, internships of scientists abroad, holding important international conferences. Its regulatory function will be implemented according to world standards of transparent distribution of finance and the quality of conducting scientific expertise and selection of bids. To date, Ukraine has launched the EU grant program on research and innovation "Horizon 2020", which is designed for seven years from 2014 to 2020.

Besides, public mechanisms of education and science management in Ukraine are on their way. In 2013, the State
"Association of Management Problems Researchers " was founded and registered on the basis of the "Lugansk Shevchenko National University". In 2015, the Public Organisation «Ukrainian Educational Research Association» (UERA) was created and registered as a voluntary nonprofit non-governmental organization based on the Ivan Franko Drohobych State Pedagogical University. On March 18, 2017 , UERA gained the status of a full member of the European Association of Educational Researchers (EERA). In Odessa, the "Association of Researchers in Public Administration" has been registered. The development of public native structures of science management, activating their activities and gaining authority among scientists, both domestic and foreign, can become an important factor in the development of scientific theory and research methodology.

Conclusions. Consequently, the analysis showed that the scientific theory of education management has its institutes for the reproduction of scientific staff, specialized councils for the defence of dissertations, communication channels for exchanging scientific information, specialized periodicals. The public education management is at the stage of formation. All these institutions are important factors in the development of research methodology in this branch of science. However, there are no specialized research institutions in the field of research on education management issues in Ukraine; the number of scientists developing this issue has decreased significantly during the last year, and the number of defended dissertations has decreased. These negative trends should be studied in order to develop effective mechanisms for managing the development of education management theories and conducting research in this area.

\title{
REFERENCES
}

1. Vasyniova N.S. Substantiation of criteria for analysis and evaluation of the development of the theory of management of higher educational institutions in Ukraine (the last quarter of the $\mathrm{XX}$ - the beginning of the XXI century) // Creation of a quality management system for administrative, social and educational services: theory and practice: materials of sciences. conf. (April 18, 2013, Luhansk): in 2 v./Ed.board: O.M. Klimochkina, Ye. Khrykov, O.Kravchenko - Lugansk: PH "LNU named after Taras Shevchenko", 2013. - v.2.

2. Gerasymchuk, Andriy Andriyovych Sociology: Textbook /A.A. Gerasymchuk, Yu.I. Paleha, O.M. Shyan; European Univ. - K.: Publishing House of the European Union, 2004. - 246 p. : tabl.

3. Information system "Competition" [E. resource]. - Access mode: http://www.vstup.info/2012/i2012okr2bf939e623-b30f4b43a9be5dbefb8dab5e.html

4. Lunyachek V. Some questions of establishment a specialty "Management of an educational institution"//Problems of modern

pedagogical education. Pedagogy and psychology. - 2013. - Issue 38 (2). - P. 264-271.

5. Methodological foundations of pedagogical research: monograph/Ye. Khrykov, A. Adamenko, V. Kurilo and others; Ed. V. Kurilo, Ye. Khrykov. - Luhansk: PH "LNU named after Taras Shevchenko", 2013. -248 p.

6. Ponomarenko V. Institutionalization of Research and Analysis of Educational Policy as an Interdisciplinary Direction//Ukrainian Scientific Journal "Education of the Region: Political Science, Psychology, Communication" No. 2 - 2010 - [E. resource] Access mode: http://social-science.com.ua/article/254

7. Hrykov Ye. Branch Specialization in Pedagogical Science // Ukrainian Pedagogical Journal. - Kyiv: NAPS of Ukraine. 2018. №1. - p. 38-46.

8. Hrykov Ye. Methodology of pedagogical research: monograph / Ye. Khrykov. - Kharkiv: FOP Panov A.M., 2017. - 237 p.

\begin{abstract}
Анализ институциональной организации науки управления образованием как фактора развития методологии исследования образования

Т. В. Сыч

Аннотация. В статье представлена характеристика институциональной организации науки управления образованием как фактора развития методологии исследования проблем управления образованием. Рассмотрены академические учреждения, занимающиеся исследованием проблем управления образованием; образовательные системы, которые воспроизводят соответствующие научные кадры; государственные и общественные структуры, которые направляют научно-педагогическую деятельность в этой отрасли; средства коммуникации в этой сфере, специализированные профессиональные научные издания; международные донорские организации и фонды, которые поддерживают исследования проблем управления образованием.
\end{abstract}

Ключевые слова: институционализация науки, управление образованием, развитие теории управления образованием, развитие методологии, методология исследования проблем управления образованием. 